\title{
КОНКОРДАЦІЯ ЕКСПЕРТІВ - ЗАПОРУКА УСПІХУ В РОЗРОБЦ СТРАТЕГІЙ РОЗВИТКУ КРАЇН В ІНДУСТРІї 4.0
}

\section{CONCORDION OF EXSPERTS IS A GUARANTEE OF SUCCESS IN DEVELOPING OF COUNTRYS DEVELOPMENT STRATEGIES IN INDUSTRY 4.0}

\author{
Грінько Ірина Миколаївна \\ кандидат економічних наук, доцент, \\ Національний технічний університет України \\ «Київський політехнічний інститут імені Ігоря Сікорського» \\ ORCID: https://orcid.org/0000-0002-8948-5686 \\ Hrinko Iryna \\ National Technical University of Ukraine \\ «lgor Sikorsky Kyiv Polytechnic Institute»
}

\begin{abstract}
У статті розглянуто важливість дослідження наукової проблеми з конкордації експертів у розробці та реалізації проєктів з розвитку країн в Індустрії 4.0. Встановлено, що узгоденість та узагальнення думок експертів команди слугує розвитку системоутворюючих елементів Індустрії 4.0, таких як: розроблення та затвердження інноваційного розвитку країн; розробці нових промислових стратегій, і утому числі запуску інноваційних технологічних процесів та інноваційної продукції; запуску національних та регіональних політик в Індустрії 4.0; фрормування окремого органу координації 4.0. Обґрунтовано та запропоновано доцільність застосування інструментів математичної статистики для узгодженості думок експертів командної роботи, а саме: розрахунок коефіцієнтів рангової кореляції Спірмена, конкордації Кендалла та проведення однофакторного дисперсійного аналізу.
\end{abstract}

Ключові слова: конкордація, експерти, розробка стратегій, розвиток країн, Індустрія 4.0.

В статье рассмотрено важность исследования научной проблемы с конкордации экспертов в разработке и реализации проектов по развитию стран в Индустрии 4.0. Установлено, что согласованность и обобщение мнений экспертов команды служит развитием системообразующих элементов Индустрии 4.0, таких как: разработка и утверждение инновационного развития стран; разработка новых промышленных стратегий, и в том числе запуск инновационных технологических процессов и инновационной продукции; запуск национальных и региональных политик в Индустрии 4.0; формирование отдельного органа координации 4.0. Обосновано и предложено целесообразность применения инструментов математической статистики для согласованности мнений экспертов командной работы, а именно: расчет коэфффициентов ранговой корреляции Спирмена, конкордации Кендалла и проведения однофакторного дисперсионного анализа.

Ключевые слова: конкордация, эксперты, разработка стратегий, развитие стран, Индустрия 4.0.

The article discusses the importance of researching a scientific problem with the concordance of experts in the development and implementation of projects for the development of countries in Industry 4.0. It has been established that the consistency and generalization of the opinions of the team's experts serves as the development of the backbone elements of Industry 4.0, such as: development and approval of the innovative development of countries; development of new industrial strategies, including the launch of innovative technological processes and innovative products; launching national and regional policies in Industry 4.0; formation of a separate coordination body 4.0 . The expediency of using the tools of mathematical statistics for the consistency of the opinions of teamwork experts has been substantiated and proposed, namely: the calculation of the Spearman's rank correlation coefficients, Kendall's concordance and the one-way analysis of variance. Kendall's method for the agreement of experts' opinions is considered and the calculation of the concordance coefficient and the calculation of Spearman's rank correlation coefficient are given. It was found that the ranking of the choice of innovative products or technology is based on several criteria, such as its prospects, competitiveness or consumer value. A matrix of ranks of types of innovative technological processes or innovative products provided by experts according to the Spearman method is presented. The sequence of five stages of application of one-factor analysis of variance in achieving the concor- 
dance of teamwork experts and the development of agreed opinions in the development of industry 4.0 development strategies is described. It is proposed to improve the system of expert selection in the management of teams of experts to the management of organizations; to develop and adapt in practice methods of checking the validity of opinions and identify reasons for reducing their reliability; combine expert assessments with mathematical and statistical methods. Concordion of experts is the basis of success in the development and implementation of strategies and projects for the development of Industry 4.0 of any country.

Keywords: concordance, experts, strategy development, country development, Industry 4.0.

Постановка проблеми. Вагомими та нагальними проблемами у розвитку Індустрії $4.0 €$ запуск системоутворюючих елементів на рівні держав (розвиток інституціоналізації), тобто розробка нових промислових стратегій усіма стейкхолдерами, прийняття та затвердження стратегій інноваційного розвитку країн світу в напрямі Індустрії 4.0., створення окремого органу координації 4.0 у кожній країні світу, запуск регіональних політик в Індустрії 4.0, підготовку експертів, які надають послуги у промислових хайтек-сегментах. Вище зазначене обумовило вибір актуальної теми дослідження, так як розробка стратегій розвитку країн світу в напрямі Індустрії 4.0 потребує не лише відбір та підготовку кваліфрікованих експертів в командній роботі, а у тому числі, їх конкордацію, що й слугує запорукою успіху в розробці та реалізації стратегій та проєктів Індустрії 4.0.

Аналіз останніх досліджень і публікацій. Вітчизняними та зарубіжними вченими та практиками присвячено чимало наукових праць з проблематики командної роботи експертів і узгодженості їх думок (конкордації) у виробленні есрективних рішень в розробці стратегій та проєктів, досягненні результативної кінцевої поставленої мети командної роботи. Серед таких праць із зазначеної наукової проблематики варто виділити роботи наступних вчених і практиків: Martine Haas \& Mark Mortensen [1]; В.О. Москаленка [2]; Р.А. Мухи [3]; Р.Г. Селіверстова [4]; А.І. Крисоватого [5]; О.М. Сохацької [5]; Р.В. Юринця [6; 7]; І.3. Савраса [7]; О. Юрчака [8]; О.І. Шерстюка [9]; О. І. Яшкіної [10] та інших.

Виділення невирішених раніше частин загальної проблеми. Аналізуючи останні дослідження та публікації 3 наукової проблематики конкордації експертів у більшій мірі переважають праці вчених та практиків з фрормування команд експертів, ефективної командної роботи експертів і значно менше присвячено досліджень узгодженості думок експертів у командній роботі, а тим паче конкордації експертів 3 питань Індустрії 4.0, що й обґрунтовує важливість обраної теми дослідження.
Формулювання цілей статті. Основною метою $€$ дослідити інструменти конкордації експертів та обґрунтувати важливість їх застосування в розробці стратегій розвитку країн в Індустрії 4.0.

Виклад основного матеріалу дослідження. Конкордацією являється узгодженість думок експертів за допомогою використання системи показників. Узгодженість та узагальнення думок експертів команди згідно різних напрямів (факторів, параметрів) зазвичай здійснюють за допомогою методів статистичного аналізу результатів вибіркового спостереження використовуючи показники варіації даних, частотність чи показники центру розподілу. Для узгодження наданих відповідей експертів командної роботи у розробці стратегій розвитку Індустрії 4.0 доцільно застосовувати інструменти математичної статистики такі як: коесріцієнти рангової кореляції Спірмена, конкордації Кендалла, проводять однофракторний дисперсійний аналіз.

Методика Кендалла щодо узгодженості думок експертів передбачає розрахунок коефріцієнта конкордації за фрормулами 1 та 1.1:

$$
W=\frac{12 S}{m^{2}\left(n^{3}-n\right)}
$$

де

$$
S=\sum_{i=1}^{n}\left(\sum_{j=1}^{m} x_{i j}-\frac{1}{2} m(n+1)\right)^{2}
$$

Коефріцієнт конкордації змінюється в межах від 0 до 1. Якщо коефіцієнт буде дорівнювати 1 , то всі експерти $(m)$ надали об'єктам (n) однакові ранги. Обраними об'єктами у даному випадку вважається інноваційна продукція чи інноваційні технологічні процеси у промисловості для розвитку Індустрії 4.0. Якщо коефіцієнт конкордації знаходиться на позначці 0 згідно результатів проведеної експертизи у виборі інноваційних технологій чи виготовленні нової продукції, то думки експертів являються не узгодженими. Узгодженість думок експертів командної роботи підтверджує значення 0,7 або 0,9. У такому разі, вважається, що більше 70\%-90\% експертів обрали однаковий об'єкт інноваційного впро- 
вадження. Тобто, при значеннях коефріцієнта $W \geq 0,7 ; W \geq 0,9$ узгодженість експертів вважається досить високого рівня.

В опитуванні може брати участь лише два експерти, або із усієї групи команди оцінюватимуть думки лише двох експертів, то у такому випадку варто застосовувати коефріцієнт рангової кореляції Спірмена. Відповідно, буде дві послідовності рангів, наприклад: $x_{11}$, $x_{21}, \ldots, x_{n 1}$ та $x_{12}, x_{22}, \ldots, x_{n 2}$.

Статистичні оцінки результатів опитування експертів варто здійснювати завдяки використанню рангової шкали, коли обирається декілька варіантів доцільності впровадження інноваційного технологічного процесу або нової продукції в промисловості. Ранжування вибору продукції чи технології здійснюється за декількома критеріями, наприклад, її перспективності, конкурентоспроможності або споживчої цінності.

Коефріцієнт рангової кореляції Спірмена розраховується за фрормулою 2:

$$
\rho=1-\frac{6 \sum_{i=1}^{n}\left(x_{i 1}-x_{i 2}\right)^{2}}{n\left(n^{2}-1\right)}=1-\frac{6 \sum_{i=1}^{n} d_{i}^{2}}{n\left(n^{2}-1\right)},
$$

де $i$ - ранг надано $i$-му виду інноваційного технологічного процесу чи інноваційної продукції першим експертом;

$\kappa$ - ранг наданий $i$-му виду інноваційного технологічного процесу чи інноваційної продукції другим експертом;

$n$ - кількість видів інноваційних технологічних процесів або інноваційної продукції, які порівнюються експертами;

$d_{i}-$ різниця між рангами для кожного 3 видів інноваційного технологічного процесу чи інноваційної продукції.

Розглянутий коефріцієнт рангової кореляції Спірмена змінюється у межах від -1 і до +1. Коли думки експертів збігаються, то коефріцієнт буде дорівнювати 1. Якщо ж навпаки буде суттєва розбіжність у думках та проставлених оцінках експертами при виборі доцільності впровадження того чи іншого інноваційного технологічного процесу або нової продукції, коефріцієнт становитиме -1.

Узгодженість думок експертів досягається тоді, коли коефріцієнт кореляції Спірмена сягне позначки 0,7, тобто збіг думок щодо вибору впровадження інноваційної продукції чи технологічного процесу буде складати $70 \%$. Якщо ж оцінки експертів не більше ніж 90\% будуть співпадати, то коефріцієнт кореляції становитиме $\rho \geq 0,9$, вважатиметься, що думки $€$ тісно узгодженими.

В опитуванні може брати участь і більше, ніж два експерти ( $m$ осіб). Найменувань об'єктів оцінювання (інноваційних технологій чи продукції), також може бути більше ніж два. У такому випадку, матриця рангів, які надають $m$ осіб (експертів) $n$ видам об'єктів, матиме наступний вигляд, який представлений у табл. 1.

В практичні експертній діяльності $€$ випадки, коли необхідно визначити ступінь міжгрупової узгодженості думок експертів. Тобто, коли експертне опитування проводять у декілька групах командної роботи експертів. Для отримання результатів оцінювання у міжгруповій узгодженості думок експертів доцільно обрати інструментарій однофакторного дисперсійного аналізу. Але, якщо дві групи експертів бере участь в опитуванні, то варто використати t-тест Стюдената для незалежних вибірок.

Застосування односракторного дисперсійного аналізу ґрунтується на виконанні п'яти послідовних етапів. На першому етапі потрібно визначити, як залежну, так і незалежну змінну; далі наступним другим кроком має бути розкладання розгорнутої (повної) дисперсії; на третьому - вимірюються ефекти; потім (четвертий етап) перевіряється зна-

Таблиця
процесів

$$
\text { чи інноваційній продукції (n) }
$$

\begin{tabular}{|l|c|c|c|c|}
\hline \multicolumn{1}{|c|}{ Об'єкт інноваційного впровадження } \\
$\begin{array}{l}\text { (вид інновації) } \\
\text { Інноваційний технологічний процес } \\
\text { або інноваційна продукція № 1 }\end{array}$ & Експерт 1 & Експерт 2 & .. & Експерт $\boldsymbol{m}$ \\
\hline $\begin{array}{l}\text { Інноваційний технологічний процес } \\
\text { або інноваційна продукція № 2 }\end{array}$ & $X_{11}$ & $X_{12}$ & $\ldots$ & $X_{1 m}$ \\
\hline ... & $\ldots$ & $X_{22}$ & $\ldots$ & $X_{2 m}$ \\
\hline $\begin{array}{l}\text { Інноваційний технологічний процес } \\
\text { або інноваційна продукція № n }\end{array}$ & $X_{n 1}$ & $X_{n 2}$ & $\ldots$ & $\ldots$ \\
\hline
\end{tabular}


чущість; п'ятий - передбачає інтерпретацію отриманих результатів оцінювання.

У практичній діяльності при виборі доцільності впровадження інноваційного об'єкту (виду інновацій) беруть участь певні групи експертів, наприклад, необхідно задіяти до командної роботи науковців, управлінців та підприємців. На першому етапі здійснюється пошук залежної змінної, тобто виставляються оцінки експертами кожної групи. Під незалежною змінною в даному випадку розуміється номер експертної групи. Визначається середнє значення кожною із груп експертів

Матриця дисперсійного аналізу доцільності впровадження інноваційного об'єкту завдяки залученню до командної роботи, наприклад трьох груп експертів представлена у табл. 2.

Другий етап, розкладання повної дисперсії передбачає необхідність розділення варіації залежної змінної на варіацію, яка обумовлена відмінністю середніх значень між групами експертів, і до цього ще варто додати обумовлену внутрішньогрупову мінливість. На даному етапі однофракторного дисперсійного аналізу повну варіацію потрібно розподілити на дві компоненти варіації, такі як: 1) міжгрупову варіацію, що характеризує варіацію між категоріями змінної; 2) внутрішньо групову - це варіація в середині кожної групи експертів.

Третій етап передбачає розрахунку виміру ефекту. Тобто, яким чином сила впливу міжгрупової варіації впливає на повну варіацію.

Четвертий етап ґрунтується на необхідності провести перевірку значущості завдяки однофракторному дисперсійному аналізі, тобто варто перевірити нульову гіпотезу.
П'ятий етап передбачає інтерпретацію результатів, які варто систематизувати після проведених розрахунків. Якщо при розрахункові нульової гіпотези щодо рівності групових середніх отримуємо результат, який не потрібно відхиляти, то це свідчить, що незалежна змінна не має впливу на залежну змінну згідно статистичної значущості. У такому випадку, середні у групах експертів мають не суттєво відрізнятися, тобто думки експертів у різних групах (науковці, управлінці, підприємці) вважатимуться узгодженими. При отриманні результати після розрахунку нульової гіпотези, який варто відхилити, тоді таку умову трактують, що ефект незалежної змінної на залежну являється статистично значущим. У цьому випадку, середнє значення залежної змінної буде різним для різних груп незалежної змінної. Запропонований коесріцієнт рангової кореляції Спірменом у практичній діяльності вважається більш простим і менш затратним в часі щодо його обчислення.

Висновки. Підсумовуючи вище проведене дослідження, варто зауважити, що завдяки конкордації можна скоординувати та узгодити дії учасників команди для досягнення інноваційного кадрового розвитку організації і країни у цілому, який має бути обумовленим суттєвим впливом зниженням витрат ресурсів та зростанням продуктивності праці. Керівництво організацій та лідери команд мають: 1) вдосконалювати систему відбору експертів, тим самим сприяючи підвищенню надійності характеристик командної думки; 2) розробляти та адаптувати методи перевірки обґрунтованості думок експертів та їх

Таблиця 2

Матриця дисперсійного аналізу доцільності впровадження інноваційного об'єкту із задіянням до командної роботи трьох груп експертів

\begin{tabular}{|c|c|c|c|}
\hline $\begin{array}{l}\text { Об'єкт інноваційного } \\
\text { впровадження } \\
\text { (вид інновації) }\end{array}$ & $\begin{array}{c}\text { Перша експертна } \\
\text { група (науковці) }\end{array}$ & $\begin{array}{c}\text { Друга експертна } \\
\text { група (управлінці) }\end{array}$ & $\begin{array}{l}\text { Третя експертна } \\
\text { група (підприємці) }\end{array}$ \\
\hline $\begin{array}{l}\text { Інноваційний технологічний } \\
\text { процес або інноваційна } \\
\text { продукція № } 1\end{array}$ & $X_{11}$ & $X_{12}$ & $X_{13}$ \\
\hline $\begin{array}{l}\text { Інноваційний технологічний } \\
\text { процес або інноваційна } \\
\text { продукція № } 2\end{array}$ & $X_{21}$ & $X_{22}$ & $X_{23}$ \\
\hline $\begin{array}{l}\text { Інноваційний технологічний } \\
\text { процес або інноваційна } \\
\text { продукція № } 3\end{array}$ & $X_{31}$ & $X_{32}$ & $X_{33}$ \\
\hline$\ldots$ & $\ldots$ & $\ldots$ & $\ldots$ \\
\hline $\begin{array}{l}\text { Інноваційний технологічний } \\
\text { процес або інноваційна } \\
\text { продукція № } \boldsymbol{n}\end{array}$ & $X_{n 1}$ & $X_{K 2}$ & $X_{c 3}$ \\
\hline
\end{tabular}


оцінок; 3) виявляти причини, які знижують достовірність експертних оцінок експертів 3 метою досягнення їх ефрективної узгодженості; 4) поєднувати експертні оцінки 3 математично-статистичними методами, що $є$ еорективним інструментом в процесів удосконаленні управлінням персоналом підприємства та колективом команди експертів зокрема.

Ефективна робота експертів у командах та досягнення конкордації є основою і запорукою успіху в розробці та реалізації стратегій та проєктів розвитку Індустрії 4.0. Зазначене $€$ фрундаментом у: інституціоналізації розви- тку промислових хайтек-сегментів на рівні будь-якої держави; прискоренні кластеризації 4.0 як на регіональному, так і національному рівні; запуску експертних програм у промисловості; залучення IT сектору до проблем розвитку внутрішнього ринку та передання досвіду впливу глобальних процесів і бізнеспрактик промисловим хайтек-секторам; прискорення розвитку промислових сегментів країн світу та їх інтернаціоналізація і інтеграція у світовий простір 4.0 чи інтеграція у європейські світові ланцюжки цінності 4.0 тощо $[11$, c. 4].

\section{СПИСОК ВИКОРИСТАНИХ ДЖЕРЕЛ:}

1. Martine Haas \& Mark Mortensen The secrets of great teamwork. Harvard Business Review. 2016. № 6. P. 70-76. URL: https://hbr.org/2016/06/the-secrets-of-great-teamwork.

2. Москаленко В.О. Сучасні підходи до фрормування команди проекту. Інтелект XXI. 2014. № 5. С. 78-86. URL: http://nbuv.gov.ua/UJRN/int_XXI_2014_5_12.

3. Муха Р.А. Організація командної роботи на підприємстві, її переваги та недоліки. Глобальні та національні проблеми економіки. 2016. Вип. 12. С. 313-317. URL: http://dspace.tneu.edu.ua/bitstream/316497/6506/1 /11\%/20Організація\%20командної\%20роботи.pdf.

4. Селіверстов Р.Г. Елементи теорії нечітких множин як засіб професіоналізації експертної діяльності в органах державного управління. Ефективність державного управління : зб. наук. пр. ЛРІДУ НАДУ / за заг. ред. проф. В. С. Загородського, доц. А. В. Ліпенцева. Львів : ЛРІДУ НАДУ, 2008. Вип. 16/17. С. 372-376.

5. Четверта промислова революція: зміна напрямів міжнародних інвестиційних потоків: монографія / за наук. ред. д.е.н., проф. А.І. Крисоватого та д.е.н., проф. О.М. Сохацької. Тернопіль : Осадца Ю.В., 2018. 478 с.

6. Юринець Р.В. Економіко-математичне моделювання утворення експертних груп. Проблеми розвитку фрінансової системи України в умовах євроінтеграції : матеріали IV міжнар. наук.-практ. конфр. Львів : ЛДФА, 2007. С. 336-338.

7. Юринець Р.В., Саврас І.3. Формування експертних груп з використанням економіко-математичних моделей рішень. Вісник соціально-економічних досліджень : зб. наук. пр. ОДЕУ / за заг. ред. М.І. Зверкова. 2008. № 30. С. 413-417.

8. Юрчак О. Консолідація експертів - як найбільша цінність і як бар'єр № 1. Інвестаазета. 2019. URL: https://investgazeta.ua/blogs/konsolidatsiya-ekspertiv-yak-najbilsha-tsinnist-i-yak-bar-er-1.

9. Шерстюк О.І. Моделі та методи компетентнісно-рольового формування команди проекту : авторефр. дис. ... канд. тех. наук : 05.13.22 «Управління проектами та програмами»; Одеський нац. політех. університет. Одеса, 2017. 21 с. URL: http://dspace.opu.ua/jspui/bitstream/123456789/5277/1/aref_SherstyukO.pdf.

10. Яшкіна О. І. Статистичні інструменти визначення узгодженості думок експертів в маркетингових дослідженнях. Наука та інновації. 2013. URL: http://ela.kpi.ua:8080/bitstream/123456789/10830/1/74.pdf.

11. Національна стратегія Індустрії 4.0 / Проект для Кабінету Міністрів України за підтримки Координатора ОБСЄ в Україні. 2019. 49 с. URL: http://www.ism.kiev.ua/images/strategy.pdf.

\section{REFERENCES:}

1. Haas M., Mortensen M. (2016) The secrets of great teamwork. Harvard Business Review, no. 6, pp. 70-76. Available at: https://hbr.org/2016/06/the-secrets-of-great-teamwork.

2. Moskalenko V.O. (2014) Suchasni pidhodi do formuvannya komandi proektu. Intelligence XXI, no. 5, pp. 78-86. Available at: http://nbuv.gov.ua/UJRN/int_XXI_2014_5_12. (in Ukrainian)

3. Muha R.A. (2016) Organizaciya komandnoyi roboti na pidpriyemstvi, iyi perevagi ta nedoliki. Global and national economic problems, no. 12, pp. 313-317. Available at: http://dspace.tneu.edu.ua/bitstream/ 316497 /6506/1/11\%/200рганізація\%20командної\%20роботи.pdf. (in Ukrainian)

4. Seliverstov R.G. (2008) Elementi teoriyi nechitkih mnozhin yk zasib profesionalizaziyi ekspertnoyi diyalnosti v organach derzhavnogo upravlinnya [Elements of the theory of fuzzy sets as a means of professionalization of expert 
activity in public administration]. In V.S. Zagorodsky \& A.V. Lipenceva (Eds.), Efectivnist dergavnogo upravlinnya Efficiency of public administration (Vols. 16-17). (Vol. 16, pp. 372-376). Lviv: LRDU NADU. (in Ukrainian)

5. Krisovatij A.I. (2018) Chetverta promislova revolyuciya: zmina napryamiv migzhnarodnih investicijnih potokiv. In A.I. Krisovatij \& O.M. Sohazka (Eds.). Ternopil: Osadca Yu.V. (in Ukrainian)

6. Yurinec R.V. (2007) Ekonomiko-matimatichne modelyuvannya utorennya ekspertnich grup. Problems of development of the financial system of Ukraine in the conditions of European integration: IV Mizhnarodna naukovopraktichna konferenciya [IV International scientific-practical conference] (Lviv, 2007) (Part 1, pp. 336-338). Lviv: LDFA. (in Ukrainian)

7. Yurinec R.V., Savras I.Z. (2008) Formuvannya ekspertnich grup z vikoristannyam ekonomiko-matematichnih modelej rishen [Formation of expert groups using economic and mathematical models of solutions]. In M.I. Zverkova (Eds.). Visnik socialno-ekonomichnih doslodzhen [Bulletin of socio-economic research], no. 30, pp. 413-417. Odesa: ODEU. (in Ukrainian)

8. Yurchak O. (2019) Konsolidaciya ecspertiv - yak najbilha cinnist i yak baryer № 1. Investgazeta. Available at: https://investgazeta.ua/blogs/konsolidatsiya-ekspertiv-yak-najbilsha-tsinnist-i-yak-bar-er-1. (in Ukrainian)

9. Sherstyuk O.I. (2017) Modeli ta metodi kompetentnisno-rolovogo formuvannya komandi proektu [Models and methods of competency-role formation of the project team]. Extended abstract of Candate's thesis. Odesa. (in Ukrainian)

10. Yashkina O.I. (2013) Statistichni instrumenti viznachennya uzgodzhenosti dumok ekspertiv v marketingovih doslidzhennyah. Science and innovation. Available at: http://ela.kpi.ua:8080/bitstream/123456789/10830/1/74.pdf. (in Ukrainian)

11. Nacionalna strategiia Industriyi 4.0 [National Industry Strategy 4.0]. Available at:http://www.ism.kiev.ua/ images/strategy.pdf. 